\title{
Dietary Non-protein Energy Sources Regulate Growth and Digestion of Barramundi Juvenile (Lates calcarifer)
}

\author{
Zhengyi Fu ${ }^{1,2,3,4}$, Rui Yang ${ }^{2,3,4}$, Zhenhua $\mathrm{Ma}^{2,3,4 *}$, Mingyang $\mathrm{Han}^{2,3,4}$ and Yifu Wang ${ }^{2,3,4}$ \\ ${ }^{1}$ Ocean College, Hainan University, Haikou, 570228, P.R. China \\ ${ }^{2}$ Tropical Aquaculture Research and Development Center, South China Sea Fisheries \\ Research Institute, Chinese Academy of Fishery Sciences, Sanya 572018, P.R. China \\ ${ }^{3}$ Key Laboratory of South China Sea Fishery Resources Exploitation and Utilization, \\ Ministry of Agriculture, Guangzhou, 510300, P.R. China \\ ${ }^{4}$ Sanya Tropical Fisheries Research Institute, Sanya 572018, P.R. China
}

\section{A B S T R A C T}

This study evaluated the effects of different dietary non-protein energy sources on growth performance, somatic parameters, histology and digestive enzymatic activity of barramundi (Lates calcarifer). Fish were fed ioso engery diets $(18 \mathrm{~kJ} / \mathrm{g}$ ) with two types of non-protein energy sources in the experimental groups and a regular diet was used as the control. The feeding trial lasted for 56 days. Results from the present study indicate that, except for weight gain and feed intake, most growth parameters of fish were not significantly affected by the experimental diets $(P>0.05)$. Lipid group had higher whole body and muscle lipid, hepatosomatic index (HSI) and intraperitoneal fat ratio (IPF). The number of goblet cells and the height of the mucosa in the HL were significantly higher than those in the other two groups. The lipase activity of $\mathrm{HL}$ and $\mathrm{HC}$ was higher than that of control group in both stomach and foregut. This study indicates that increasing the proportion of lipid in the dietary improves growth performance and digestion performance of barramundi, while higher proportions of carbohydrate in the diet don't affect their growth performance. Considering the cost of production, carbohydrate could be a potential energy supplementing source.
Article Information Received 25 April 2020 Revised 30 May 2020 Accepted 20 June 2020 Available online 08 October 2021

Authors' Contribution ZM designed this study. ZF, RY, MH and $Y W$ conducted the tests. $Z F$ and ZM drafted the manuscript.

Key words

Feed, Growth performance, Somatic parameters, Histology, Digestive enzymatic activity

\section{INTRODUCTION}

$\mathrm{D}$ ietary lipid and carbohydrate as energy sources in fish aquaculture are considered as partial substitution of dietary protein and increased feed efficiency (Boujard, 2004; Hillestad et al., 1998). In intensive aquaculture, the major cost of production is the cost of feed (Muzinic et al., 2006). High-efficiency and economic dietary should be provided with energy from non-protein energy sources as much as possible, to reduce the consumption of protein, and also reduce the pollution of water environment caused by large amount of nitrogen excretion caused by high-protein dietary (Panserat et al., 2000). As a non-protein energy source, lipid not only provides energy for fish, but also acts as carrier of fat-soluble vitamins and synthetic material for certain vitamins and hormones. It is generally accepted that fish are less carbohydrate efficient, and carnivorous fish are less efficient than herbivorous and omnivorous fish (NRC, 2011). However, some studies have revealed that incorporation of appropriate levels of carbohydrates

\footnotetext{
* Corresponding author: zhenhua.ma@hotmail.com 0030-9923/2021/0006-2279 \$ 9.00/0

Copyright 2021 Zoological Society of Pakistan
}

in diet can improve growth performance in several fish species (Hemre et al., 2002; Ren et al., 2011). Adequate carbohydrate can save the consumption of protein and lipid to provide energy, thus effectively preventing the degradation of protein and lipids (Enes et al., 2006; Stone, 2003). It has been found that Oncorhynchu smykiss accelerates the degradation of muscle protein when it lacks carbohydrate (Peragón et al., 1999).

As a kind of feed material with high energy density, lipid has practical significance for improving growth performance (Glencross, 2006). Study has shown that dietary crude lipid had significant dose response effect on growth of Gulf corvina (Cynoscion. othonopterus) (González-Félix et al., 2015). Even in several kinds of fish, high dietary lipid level is acceptable. It has no negative effect on feed utilization, fish growth, and fish intestine and liver health when triploid rainbow trout (Oncorhynchus mykiss) was fed high-lipid diet (up to 29.4\%) (Meng et al., 2019). Furthermore, changing the amount of dietary carbohydrate did not significantly reduce the growth indicators such as protein efficiency ratio, and even the utilization of carbohydrate by fish could be equal to or even exceed that of lipid under certain conditions. For example, in Japanese seabass (Lateolabrax japonicus), 
the provision of adequate dietary cornstarch $(>18 \%)$ could improve the growth performance (Zheng et al., 2015). It has been found that although no differences among diets are observed on growth and feed utilization in European sea bass (Dicentrarchus labrax); however, the protein efficiency ratio is higher in the high carbohydrate group (Castro, 2015).

Barramundi (Lates calcarifer) is an important aquaculture species in south-east Asia and Australia (FAO, 2019; Ngoh et al., 2015). It has become a widely cultivated aquaculture species because of its high tolerance for highdensity culture environment and its easy propagation and easy adaptability to artificial pellets at young stage (Liu et al., 2018; Ma et al., 2018, 2019). Moreover, the fish grows rapidly as it merely takes 6 months to 2 years to reach the commercial size (Ma et al., 2019). Improving growth performance is critical for aquaculture species including barramundi. The key to improve the growth performance is the suitable feed formula. In the present study, fish oil and a-starch were used as non-protein energy sources to evaluate the growth performance and digestion response of fish to dietary lipids and carbohydrate. The results provide insights for further understanding the usage of lipids and carbohydrates in fish feed.

\section{MATERIALS AND METHODS}

\section{Experiment design and system}

Barramundi juveniles (wet weight $33.69 \pm 3.63 \mathrm{~g}$, total length $12.08 \pm 2.13 \mathrm{~cm}$ ) were produced by Tropical Aquaculture Research and Development Center, Sanya, China, and reared in the indoor recirculating aquaculture system. A total of 117 fish were randomly assigned to 9-tanks (800 L) for a 12-days acclimation, and fed with experimental diets. In each experiment tank, 13 fish were assigned, and the diet treatments were randomly assigned to the experimental tanks in triplicate. Upon completion of acclimation, feeding trial was conducted and the experiment lasted 8 weeks. Fish were fed ad libitum twice a day at 8:00 am and 4:00 pm. The experiment was conducted in outdoor seawater tanks. The water was changed $1 \mathrm{~h}$ after feeding, with 50\% water exchange in tank volume each time. Natural filtered seawater was used in this study. During the experimental period, the water quality parameters were measured daily and were maintained at ammonia nitrogen $<0.1 \mathrm{mg} \mathrm{L}^{-1}$, nitrite nitrogen $<0.02$ $\mathrm{mg} \mathrm{L}^{-1}, \mathrm{pH} 7.8$, and dissolved oxygen $>7.0 \mathrm{mg} \mathrm{L}^{-1}$. At the end of experiment, all fish were anaesthetized in $7 \mathrm{mg} \mathrm{L}^{-1}$ eugenol (Shangchi Dental Material Co., Ltd., Changshu, China) before handling and sampling to comply with the animal ethic protocol approved by the Animal Welfare Committee (E437-16). All fish in each tank were weighed to assess growth performance and three fish were sampled from each tank for somatic parameters, histological and biochemical analyses.

Three iso-energy diets (Table I) were prepared in Tropical Aquaculture Research and Development Center. According to the general nutritional requirements of barramundi, the control group (C) used the diet formula according to crude protein $475 \mathrm{~g} \mathrm{~kg}^{-1}$, crude fat $100 \mathrm{~g} \mathrm{~kg}^{-}$ ${ }^{1}$, and nitrogen-free extract $180 \mathrm{~g} \mathrm{~kg}^{-1}$. In the experimental group, fish oil and $\alpha$-starch were used as the source of lipid and carbohydrate, respectively. The crude fat in the lipid group (HL) increased to $160 \mathrm{~g} \mathrm{~kg}^{-1}$, and the nitrogen-free extract in carbohydrates group (HC) increased to $220 \mathrm{~g}$ $\mathrm{kg}^{-1}$. All ingredients were crushed and sieved $(0.2 \mathrm{~mm}$ mesh size), mixed with a food mixer (Guangdong Lifeng Co., Ltd., China) and then blended with the oils. Pellets ( $4 \mathrm{~mm}$ diameter) were then produced with a pelletizer (Shandong Hengfeng Co., Ltd., China) and air-dried at room temperature $\left(25^{\circ} \mathrm{C}\right)$. All diets were sealed in plastic bags and stored at $-20^{\circ} \mathrm{C}$ until used.

\section{Proximate composition analysis}

Moisture was determined by oven drying to a constant weight at $103{ }^{\circ} \mathrm{C}$ in an air-blower-driven drying closet (Nocchi Instrument Co., Ltd., China). Total nitrogen (\% dry weight) was determined using a rapid $\mathrm{N}$ exceed (Elementar Co., Ltd., Germany). Crude protein content was calculated as $\%$ nitrogen $\times 6.25$. Ash ( $\%$ dry weight $)$ was quantified after heating $2 \mathrm{~g}$ samples at $650{ }^{\circ} \mathrm{C}$ for $3 \mathrm{~h}$ in a muffle furnace (Labotery Instrument Co., Ltd., China). Crude lipid (\% dry weight) was determined by ether extraction using a Soxtec System (Zhejiang Tuopu Instrument Co., Ltd., China).

\section{Histological analysis}

The foregut of three fish was collected and fixed in $4 \%$ paraformaldehyde for $24 \mathrm{~h}$, dehydrated in graded ethanol concentrations. The dehydrated tissues were embedded in paraffin blocks and sliced in a series of transverse sections (4 $\mu \mathrm{m}$ thick) using a Leica RM 2016 rotary microtome (Shanghai Leica Instrument Co., Ltd., China). Hematoxylin-eosin (HE) stain was used for general histological analysis. Each slide, with tissue sections, was mounted permanently using neutral balsam. The sections were scanned using a Pannoramic 250/MIDI scanner (3D HISTECH Co., Ltd., Hungary), and Caseviewer 2.0 (3D HISTECH Co., Ltd., Hungary) was used for viewing, image collection, and data measurement. For each gut sample, three cross-sections were quantified for goblet cell number. Mucosal height and muscularis thickness were quantified by taking 10 measurements per foregut section. 
Table I. Feed composition (g $\left.\mathbf{k g}^{-1}\right)$, proximate composition of the diets (air-dry basis $\mathrm{g} \mathrm{kg}^{-1}$ ) and gross energy content $\left(\mathrm{MJ} \mathrm{kg}{ }^{-1}\right)$ in three experimental diets.

\begin{tabular}{llll}
\hline Ingredients & C & HL & HC \\
\hline Fish meal & 560 & 560 & 560 \\
Peeled soybean meal & 238 & 178 & 188 \\
a-starch & 100 & 100 & 150 \\
Fish oil & 60 & 120 & 60 \\
Choline chloride & 2 & 2 & 2 \\
Vitamin premix* & 10 & 10 & 10 \\
Mineral premix* & 10 & 10 & 10 \\
Calcium dihydrogen phosphate & 10 & 10 & 10 \\
Ethoxy quin & 10 & 10 & 10 \\
Total & 1000 & 1000 & 1000 \\
Proximate composition & & & \\
Dry matter & 929.91 & 914.06 & 931.97 \\
Crude protein & 474.92 & 445.74 & 451.42 \\
Lipid & 99.89 & 153.14 & 94.03 \\
Ash & 173.61 & 167.04 & 167.12 \\
Nitrogen-free extract & 179.99 & 145.04 & 218.10 \\
Gross energy (kJ/g)* & 18.26 & 19.08 & 18.13 \\
\hline
\end{tabular}

C, control; HL, lipid diet; HC, carbohydrate diet.

*Vitamin premix ( $\mathrm{mg} \mathrm{kg}^{-1}$ diet or specified): vitamin A 9000000 (IU kg-1 diet), vitamin D 2500000 (IU kg ${ }^{-1}$ diet), vitamin $\mathrm{K}_{3} 600$ (IU kg-1 diet),vitamin E 500 (IU kg-1 diet),vitamin $\mathrm{B}_{1}$ 3200,vitamin $\mathrm{B}_{2} 10900$,vitamin $\mathrm{B}_{5} 20000$,vitamin $\mathrm{B}_{6} 5000$,vitamin $\mathrm{B}_{12}$ 1160,vitamin C 5 0000,niacin 400 , folic acid 50,calcium pantothenate 200,phaseomannite 1500 ,biotin 2; *Mineral premix ( $\mathrm{mg} \mathrm{kg}^{-1}$ diet or specified): $\mathrm{MgSO}_{4} \cdot 7 \mathrm{H}_{2} \mathrm{O} 300 ; \mathrm{KCl}$ $70 ; \mathrm{KI} 1.5 ; \mathrm{ZnSO}_{4} \cdot 7 \mathrm{H}_{2} \mathrm{O} 14 ; \mathrm{MnSO}_{4} \cdot 4 \mathrm{H}_{2} \mathrm{O} 3 ; \mathrm{CuCl}_{2} 5 ; \mathrm{CoCl}_{2} \cdot 6 \mathrm{H}_{2} \mathrm{O} 0.5$ FeSO $\cdot 7 \mathrm{H}_{2} \mathrm{O} 15 ; \mathrm{KH}_{2} \mathrm{PO}_{4} \cdot \mathrm{H}_{2} \mathrm{O} 4.5$ ( $\mathrm{g} \mathrm{kg}^{-1}$ diet $) ; \mathrm{CaCl}_{2} 2.8$ ( $\mathrm{g} \mathrm{kg}^{-1}$ diet $) ;$ *The dietary energy was calculated as protein: $23.64 \mathrm{MJ} \cdot \mathrm{kg}^{-1}$,lipid: 39 . $54 \mathrm{MJ} \cdot \mathrm{kg}^{-1}$, carbohydrate: $17.15 \mathrm{MJ} \cdot \mathrm{kg}^{-1}$.

\section{Enzymatic assays}

The stomach and foregut of three fish from each tank were pooled and immediately preserved in liquid nitrogen. For each assay, pooled samples from each tank were partially thawed, weighed and homogenized using a tissue homogenizer on ice in five volumes of $0.2 \mathrm{M} \mathrm{NaCl}$ $(\mathrm{w} / \mathrm{v})$. The suspensions were centrifuged at 3,500 rpm for $10 \mathrm{~min}$ at $4{ }^{\circ} \mathrm{C}$. The activities of lipase, amylase and pepsin in stomach, foregut and the protein concentration of the enzyme extracts were determined by commercial kit (Nanjing Jiancheng Bioengineering Institute, Nanjing, China). All enzyme assays were performed in triplicates.

\section{Calculations and statistical analysis}

Specific growth rate $(\mathrm{SGR})=100 \times\left(\ln \left(\mathrm{W}_{\mathrm{f}}\right)-\ln \left(\mathrm{W}_{\mathrm{i}}\right)\right) / \Delta \mathrm{T}$ $\mathrm{W}_{\mathrm{f}}$ was the final body weight; $\mathrm{W}_{\mathrm{i}}$ was the initial body weight; and $\Delta \mathrm{T}$ was the experimental duration.

Feed conversion ratio $(F C R)=$ dry feed fed/body wet weight gain

Feed intake $(\mathrm{FI})=($ feed consumed per tank/fish $) /$ day

Protein efficiency ratio $(\mathrm{PER})=$ total weight gain/ protein intake

Condition factor $(\mathrm{CF})=100 \times[($ body weight $) /($ body length) ${ }^{3}$ ]

Viscera ratio $(\mathrm{VR})=100 \times[$ viscera weight/whole body weight]

Hepatosomatic index $(\mathrm{HSI})=100 \times[$ liver weight $/$ whole body weight]

Intraperitoneal fat ratio $(\mathrm{IPF})=100 \times[$ intraperitoneal fat weight/whole body weight]

The data are expressed as the mean \pm standard deviation (SD). Statistical analyses were carried out by PASW Statistics (Version 18.0). Comparisons between different groups were conducted by one-way ANOVA and LSD test, and significant difference was set at $P<0.05$. All percentage data were transformed using square root to satisfy the assumptions of ANOVA.

\section{RESULTS}

\section{Growth performance}

The growth performance of fish is presented in Table II. Final weight, SGR, survival rate, FCR and PER did not show significant differences among the three groups. Only WG and FI showed significant differences between treatments $(P$ $<0.05)$. The difference between the HL and control groups was significant $(P<0.05)$, but there was no significant difference between the $\mathrm{HC}$ and the $\mathrm{C}$ group $(P>0.05)$.

Table II. Effects of three experimental diets on growth performance of Lates calcarifer.

\begin{tabular}{|c|c|c|c|}
\hline \multirow{2}{*}{$\begin{array}{l}\text { Productivity } \\
\text { index }\end{array}$} & \multicolumn{3}{|c|}{ Experimental diet } \\
\hline & $\mathbf{C}$ & HL & HC \\
\hline $\begin{array}{l}\text { Initial weight (g } \\
\text { fish }^{-1} \text { ) }\end{array}$ & $32.85 \pm 0.67$ & $32.76 \pm 2.15$ & $35.31 \pm 6.19$ \\
\hline $\begin{array}{l}\text { Final weight (g } \\
\text { fish }^{-1} \text { ) }\end{array}$ & $44.36 \pm 2.30$ & $48.17 \pm 3.15$ & $49.46 \pm 5.58$ \\
\hline WG $\left(\mathrm{g} \mathrm{fish}^{-1}\right)$ & $11.51 \pm 2.41^{b}$ & $15.41 \pm 1.98^{\mathrm{a}}$ & $14.15 \pm 0.71^{\mathrm{ab}}$ \\
\hline $\operatorname{SGR}\left(\% \mathrm{~d}^{-1}\right)$ & $0.53 \pm 0.10$ & $0.69 \pm 0.07$ & $0.61 \pm 0.11$ \\
\hline Survival (\%) & $100 \pm 0$ & $97.44 \pm 4.44$ & $92.31 \pm 7.69$ \\
\hline FI $\left(g_{\text {fish }}^{-1} d^{-1}\right)$ & $0.63 \pm 0.07^{\mathrm{b}}$ & $0.83 \pm 0.13^{\mathrm{a}}$ & $0.64 \pm 0.08^{\mathrm{ab}}$ \\
\hline FCR & $3.12 \pm 0.46$ & $3.09 \pm 0.76$ & $2.54 \pm 0.21$ \\
\hline $\operatorname{PER}(\%)$ & $0.68 \pm 0.10$ & $0.76 \pm 0.20$ & $0.88 \pm 0.07$ \\
\hline
\end{tabular}

Data are given as the mean \pm SD. In the same row values with same small letter superscripts or no letter superscripts mean no significant differences $(P>0.05)$; different small letter superscripts mean significant differences $(P<0.05)$. WG, Weight gain; SGR, specific growth rate; FI, feed intake; FCR, feed conversion rate; PER, protein efficiency ratio. For other abbreviations, see Table I. 


\section{Proximate composition and somatic parameters}

There was no significant difference in moisture content among the three groups $(P>0.05$, Table III). The crude protein in the whole body and muscle of the HL group was significantly lower than that of the other two groups $(P<0.05)$, and the crude fat was significantly higher than that of the other two groups $(P<0.05)$. The ash content in the HL group was significantly lower than that in the other two groups $(P<0.05)$. In muscles, the ash content was significant different in $\mathrm{HC}$ compared with $\mathrm{C}$ $(P<0.05)$. There were no significant differences in $\mathrm{CF}$ and VR between the groups $(P>0.05$, Table III). The HSI and IPF had significant differences $(P>0.05)$ between the groups, and HL showed the highest values for HSI and IPF.

Table III. Effects of three experimental diets on body composition and somatic parameters in Lates calcarifer.

\begin{tabular}{llll}
\hline Items & \multicolumn{3}{c}{ Experimental diet } \\
\cline { 2 - 4 } & C & HL & HC \\
\hline Whole body composition & & & \\
Moisture contect \% & $70.41 \pm 0.75$ & $67.94 \pm 1.03$ & $68.81 \pm 2.06$ \\
Crude protein (N\% x 6.25) & $63.19 \pm 0.30^{\mathrm{a}}$ & $54.27 \pm 1.25^{\mathrm{c}}$ & $61.30 \pm 0.19^{\mathrm{b}}$ \\
Ash content \% DW & $18.17 \pm 0.24^{\mathrm{a}}$ & $16.92 \pm 0.21^{\mathrm{b}}$ & $18.31 \pm 0.13^{\mathrm{a}}$ \\
Crude lipid \% DW & $18.13 \pm 0.44^{\mathrm{c}}$ & $26.89 \pm 0.39^{\mathrm{a}}$ & $20.11 \pm 0.53^{\mathrm{b}}$ \\
Muscle composition & & & \\
Moisture contect \% & $78.54 \pm 1.02$ & $78.08 \pm 2.98$ & $77.80 \pm 0.39$ \\
Crude protein(N\% x 6.25) & $90.07 \pm 1.03^{\mathrm{a}}$ & $88.04 \pm 0.75^{\mathrm{b}}$ & $90.34 \pm 0.73^{\mathrm{a}}$ \\
Ash content \% DW & $5.84 \pm 0.08^{\mathrm{a}}$ & $5.77 \pm 0.08^{\mathrm{ab}}$ & $5.66 \pm 0.06^{\mathrm{b}}$ \\
Crude lipid \% DW & $2.19 \pm 0.11^{\mathrm{b}}$ & $3.81 \pm 0.19^{\mathrm{a}}$ & $2.03 \pm 0.10^{\mathrm{b}}$ \\
Somatic parameters & & & \\
CF & $3.42 \pm 0.05$ & $3.62 \pm 0.04$ & $3.39 \pm 0.47$ \\
VR & $8.28 \pm 0.47$ & $9.46 \pm 0.66$ & $8.04 \pm 2.22$ \\
HSI & $1.47 \pm 0.27^{\mathrm{ab}}$ & $1.96 \pm 0.27^{\mathrm{a}}$ & $1.36 \pm 0.25^{\mathrm{b}}$ \\
IPF & $1.91 \pm 0.24^{\mathrm{b}}$ & $3.84 \pm 0.59^{\mathrm{a}}$ & $1.48 \pm 0.32^{\mathrm{b}}$ \\
\hline
\end{tabular}

Data are given as the mean \pm SD. In the same row, values with same small letter superscripts or no letter superscripts mean no significant differences $(P>0.05)$; different small letter superscripts mean significan differences $(P<0.05)$. CF, Condition factor; VR, Viscera ratio; HSI, Hepatosomatic index; IPF, Intraperitoneal fat ratio.

For other abbreviations, see Table I.

\section{Histology}

In this study, the morphological structure of the foregut of groups was different (Fig. 1), which was mainly reflected in the number of goblet cells and the mucosal height. The number of goblet cells and the height of the mucosa in the HL were significantly higher than those in the other two groups. In $\mathrm{C}$ and $\mathrm{HC}$ group, the number of $\mathrm{HC}$ goblet cells and the height of mucosal were significantly higher than that of $\mathrm{C}(P<0.05$, Fig. 1d, e). There was no significant difference in muscularis thickness between the three groups $(P>0.05)$.
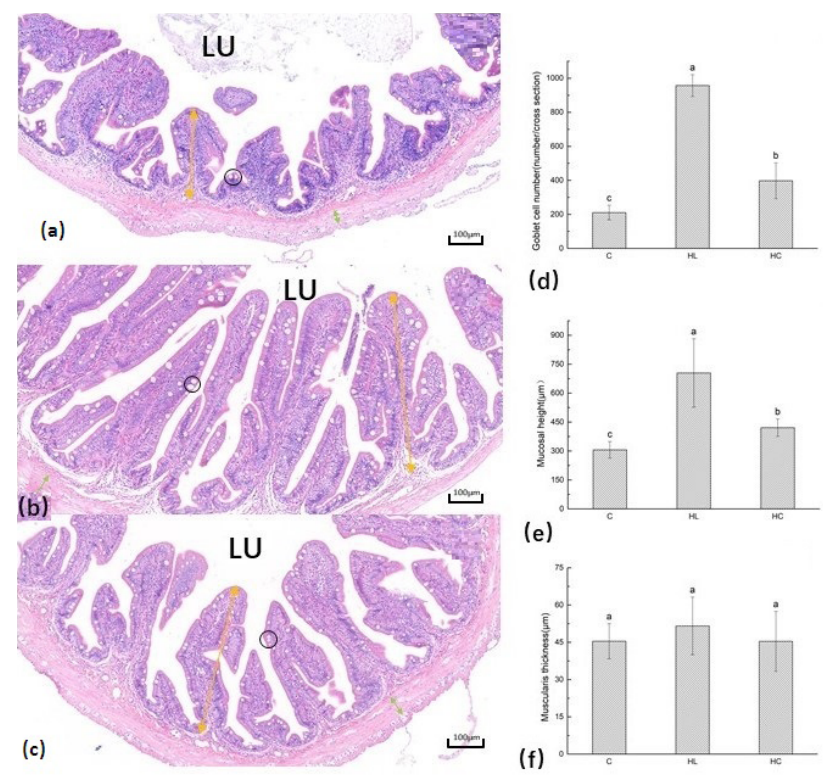

(d)

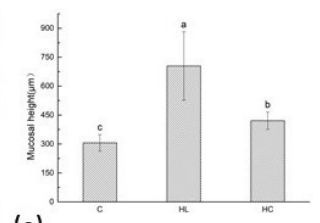

(e)

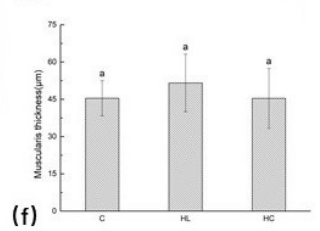

Fig. 1. The gastrointestinal tract of barramundi is influenced by different diets. Representative foregut histological sections (20×magnification) are shown on the left (Panels $\mathrm{a}-\mathrm{C} ; \mathrm{b}-\mathrm{HL} ; \mathrm{c}-\mathrm{HC})$. Circle indicate the location of goblet cell; Yellow double-arrow line segments indicate the height of the mucosa; green double-arrow line segments indicate muscularis thickness; LU: lumen. Average activity of goblet cell number (Panel d), mucosal height (Panel e) and were muscular thickness (Panel f) measured from sections of the foregut barramundi fed experimental diet (C, HL, HC). Different superscript letters indicate significant differences among treatments $(P<0.05)$. Error bars represent standard error.

\section{Digestive enzymatic activity}

In stomach, the lipase activity of HL was significantly higher than that of the other two groups $(P<0.05)$, and there was no significant difference in amylase and pepsin activity between groups $(P<0.05)$. In foregut, the lipase activity in HL was significantly higher than that in other two groups $(P<0.05)$, and there was no significant difference in amylase activity (Fig. 2, $P>0.05$ ).

\section{DISCUSSION}

Fish oil and $\alpha$-starch are commonly used as nonprotein energy sources in aquatic animal feed. Marine oils such as cod oil, sardine oil and other fish oil are more easily digested than terrestrial oils such as soy oil and palm oil. With fish oil as the lipid source in the dietary 
can provide essential fatty acids (NRC, 2011). $\alpha$-starch is a gelatinized starch obtained after liquefaction by thermally stable $\alpha$-amylase and high temperature extrusion (Vasanthan et al., 2001). Studies indicate that increasing carbohydrate utilization in carnivorous fish can be achieved by gelatinizing starches (Krogdahl et al., 2005). To sum up, in the present study, fish oil and $\alpha$-starch were used as non-protein energy sources, because they could be more utilized by fish and the negative effects on growth caused by the low utilization of added energy sources were excluded.
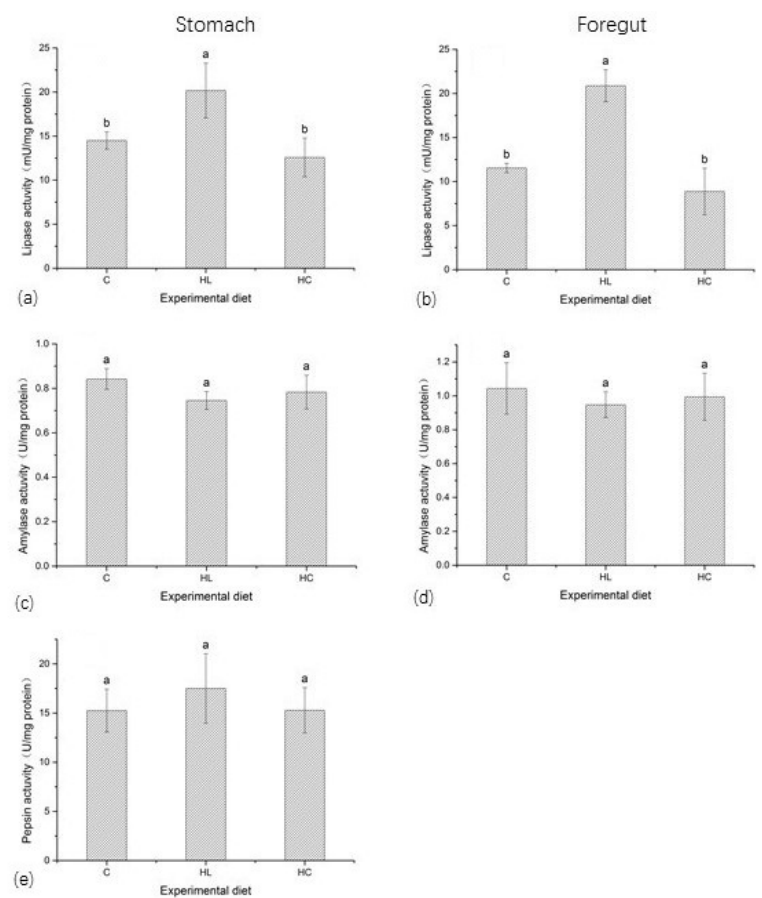

Fig. 2. Activity of lipase, amylaseand and pepsin in barramundi fed experimental diet. Different superscript letters indicate significant differences among treatments $(P<0.05)$. Error bars represent standard error.

In the present study, there was no significant differences in most growth parameters among the three groups. The results indicated that the types of energy substances could not significantly affect the growth performance of the barramundi, and the proportion of nonprotein energy substances in the diet could be increased appropriately. Similar results have been reported for barramundi by Catacutan and Coloso (1997). Only two different growth parameters, WG and FI, showed increase level in HL. In fish, voluntary FI is influenced by dietary, environmental and physiological factors (Magnoni et al., 2018). Many previous studies have shown that the fish adjust their feed intake according to their own energy requirements, so energy is one of the most important factors affecting their feed intake (Nankervis et al., 2000). However, in the present study, the feed energy of the three groups was similar. Therefore, the above phenomenon may be caused by other reasons, such as the attractiveness of fish oil (Wang et al., 2005). In terms of physical factors of feed, compared with the other two groups, the amount of a-starch added in HL group was relatively little, and the feed particle adhesion was low. The feed structure was looser and easier to swallow, which may have better palatability for the barramundi. It is generally believed that carnivorous fish have better palatability with moderate hardness feed (Sørensen, 2012).

In most fish, the positive correlation of whole-body lipid with dietary fish oil levels is due to lipid deposition in tissues and viscera (Gómez-Requeni et al., 2013; Guo et al., 2019). In the present study, a significant increase in crude lipid in HL's whole body and muscle directly led to a decrease in the proportion of crude protein and crude ash. The present results are consistent with those of Schrama et al. (2011) who also observed higher level of lipid in the whole body of Nile tilapia (Oreochromis niloticus) fed diets high in lipid. Moreover, HSI and IPF followed the same trend with the whole body and muscle crude lipid indicating that the lipid intake of the barramundi was deposited not only in the muscle, but also in the liver and intraperitoneal adipose tissue. Studies have shown that in most perciformes, the intraperitoneal adipose tissue was relatively developed and lipid was prone to accumulate in it (Ren et al., 2018), IPF may change significantly. This phenomenon also has been found in other fish (Jiang et al., 2015; Torfi Mozanzadeh et al., 2017; Zhao et al., 2016). But excessive deposition of fat in the intraperitoneal adipose tissue is not favorable for storage and product quality. In commercial aquaculture practice, people are more interested in the fillet lipid composition than whole body lipid (Helland and Grisdale-Helland, 1998; NRC, 2011). Carbohydrates could be converted into lipid in the body, but the efficiency of lipid deposition is not as obvious as lipid (Glencross et al., 2017). The added carbohydrate reduces the decomposition of proteins to provide energy, and improves its utilization rate (Zhou et al., 2016). In the present study, there was no difference in the muscle crude protein, indicating that under the dietary level of present experiment, $\mathrm{HC}$ reduced the addition of protein and increased the addition of carbohydrate, which had little effect on the retention of body protein, but increased the PER.

The foregut is the main part of the digestive system of barramundi that absorbs nutrients, and its structure is very sensitive to the change in diet. The number of goblet cells, the height of mucosa and the muscular is important 
intestinal structural parameters reflecting the degree of intestinal health (Ma et al., 2018; Sun et al., 2018). Goblet cells have the function of secreting mucus, they are the main source of mucin secretion. Mucin secretion could protect the inner surface of the intestine from pathogens and lubricates the gut content to ease its passing. Damage to intestinal health, such as intestinal infections, would have the reduced levels of goblet cell response and mucin production, enough goblet cells might have a positive effect on host defense system of the gut (Kim and Khan, 2013). The control group had significantly fewer goblet cells than the other two testing groups, which may indicate that non-protein energy sources play a positive role in intestinal health with higher mucosal height as well as augmented surface area of the gut mucosa (Merrifield et al., 2011). This is a positive effect on fish gastrointestinal morphology (Heidarieh et al., 2012). In this experiment, the height of the mucosa was significantly increased in the HL group, indicating that adding lipid in a certain range would enhance its digestive capacity.

Growth is a complex phenomenon that partly relies on the digestive capabilities of an organism, and the activity of digestive enzymes is an important parameter reflecting the digestibility (Babaei et al., 2017). In this study, different types of energy sources only had significant effect on lipase activity, suggesting that dietary lipid was correlated with lipid digestibility in the foregut (Mohanta et al., 2008; Trenzado et al., 2018). Carnivorous fish commonly consume fat-rich food, which can stimulate lipase activity in their digestive tract (Ma et al., 2014; Wang et al., 2018). There was no significant difference in amylase with different non-protein energy sources added. In this experiment, the range of nitrogen-free extracts was 143-218 $\mathrm{g} \mathrm{kg}^{-1}$ and did not reach very low level. High carbohydrate content limited capacity to utilize carbohydrate of some carnivorous fish (Hilton and Atkinson, 1982; $\mathrm{Hu}$ et al., 2007; Ren et al., 2011). Amylase activity may have reached a higher level within its ability range under the conditions of this experiment. In cobia (Rachycentron canadum L.), it was found that only when carbohydrate was added at 13-184 g kg-1 amylase showed significant difference (Ren et al., 2011). There was no significant difference in pepsin activity among the three experimental groups, indicating that addition of lipid, carbohydrate and reduced protein may not have significant effect on the activity of pepsin. Pepsin activity remained independent of protein quality and quantity, confirming the investigations on Tilapia mossambica (L.) (Nagase, 1964), Brycon melanopterus (Reimer, 1982), Colossoma macropomum (Kohla et al., 1992) and Pseudoplatystoma corruscans (Lundstedt et al., 2004). As gastric fluid production is only stimulated by the mechanical friction of the feed, the pepsin activity per unit of gastric liquid remained nearly the same while the absolute activity increased (Kohla et al., 1992).

\section{CONCLUSION}

The results of this experiment showed that when the barramundi was fed with the same amount of energy, the diet with a high proportion of lipid had a positive effect on its growth performance and digestion. Compared with the control group, the diet with high proportion of carbohydrate had no significant effect on growth performance and digestion. Therefore, from the point of view of increasing the growth rate and energy deposition, the proportion of lipid added to the diet of barramundi can be appropriately increased. From the point of view of saving the cost of feed, increasing the proportion of adding carbohydrate will not have a negative effect on growth, so it is feasible to save feed cost.

\section{ACKNOWLEDGEMENTS}

This study was financially supported by Guangxi Innovation Driven Development Special Fund Project (Guike AA18242031), Central Public-interest Scientific Institution Basal Research Fund, South China Sea Fisheries Research Institute, CAFS (2017ZD01, 2018ZD01), and Key Research and Development Project of Hainan Province (ZDYF2017036, ZDYF2018096).

\section{Statement of conflict of interest}

The authors have declared no conflict of interest.

\section{REFERENCES}

Babaei, S., Abedian-Kenari, A., Hedayati, M. and Yazdani-Sadati, M.A., 2017. Growth response, body composition, plasma metabolites, digestive and antioxidant enzymes activities of Siberian sturgeon (Acipenser baerii, Brandt, 1869) fed different dietary protein and carbohydrate: lipid ratio. Aquacul. Res., 48: 2642-2654. https://doi. org/10.1111/are.13096

Boujard, T., 2004. Regulation of feed intake, growth, nutrient and energy utilisation in European sea bass (Dicentrarchus labrax) fed high fat diets. Aquaculture, 231: 529-545. https://doi. org/10.1016/j.aquaculture.2003.11.010

Castro, C., 2015. Dietary carbohydrate and lipid source affect cholesterol metabolism of European sea bass (Dicentrarchus labrax) juveniles. Br. J. Nutr., 114: 1143-1156. https://doi.org/10.1017/ S0007114515002731 
Catacutan, M.R. and Coloso, R.M., 1997. Growth of juvenile Asian seabass,Lates calcarifer, fed varying carbohydrate and lipid levels. Aquaculture, 149: 137-144. https://doi.org/10.1016/S00448486(96)01432-9

Enes, P., Panserat, S., Kaushik, S. and Oliva-Teles, A., 2006. Effect of normal and waxy maize starch on growth, food utilization and hepatic glucose metabolism in European sea bass (Dicentrarchus labrax) juveniles. Comp. Biochem. Physiol., 143: 89-96. https://doi.org/10.1016/j.cbpa.2005.10.027

FAO, 2019. Lates calcarifer. In: Cultured aquatic species information programme (ed. M.A. Rimmer). FAO Fisheries and Aquaculture Department, Rome.

Glencross, B., 2006. The nutritional management of barramundi, Lates calcarifer: A review. Aquacult. Nutr., 12: 291-309. https://doi.org/10.1111/j.13652095.2006.00410.x

Glencross, B.D., Blyth, D., Bourne, N., Cheers, S., Irvin, S. and Wade, N.M., 2017. An analysis of partial efficiencies of energy utilisation of different macronutrients by barramundi (Lates calcarifer) shows that starch restricts protein utilisation in carnivorous fish. Br. J. Nutr., 117: 500-510. https:// doi.org/10.1017/S0007114517000307

Gómez-Requeni, P., Bedolla-Cázares, F., Montecchia, C., Zorrilla, J., Villian, M., Toledo-Cuevas, E.M. and Canosa, F., 2013. Effects of increasing the dietary lipid levels on the growth performance, body composition and digestive enzyme activities of the teleost pejerrey (Odontesthes bonariensis). Aquaculture, 416-417: 15-22. https://doi. org/10.1016/j.aquaculture.2013.08.027

González-Félix, M.L., Minjarez-Osorio, C., PerezVelazquez, M. and Urquidez-Bejarano, P., 2015. Influence of dietary lipid on growth performance and body composition of the Gulf corvina, Cynoscion othonopterus. Aquaculture, 448: 401-409. https:// doi.org/10.1016/j.aquaculture.2015.06.031

Guo, J., Zhou, Y., Zhao, H., Chen, W., Chen, Y. and Lin, S., 2019. Effect of dietary lipid level on growth, lipid metabolism and oxidative status of largemouth bass, Micropterus salmoides. Aquaculture, 506: 394-400. https://doi.org/10.1016/j.aquaculture.2019.04.007

Heidarieh, M., Mirvaghefi, A.R., Akbari, M., Farahmand, H., Sheikhzadeh, N., Shahbazfar, A.A. and Behgar, M., 2012. Effect of dietary Ergosan on growth performance, digestive enzymes, intestinal histology, hematological parameters and body composition of rainbow trout (Oncorhynchus mykiss). Fish Physiol. Biochem., 38: 1169-1174. https://doi.org/10.1007/s10695-012-9602-8
Helland, S.J. and Grisdale-Helland, B., 1998. Growth, feed utilization and body composition of juvenile Atlantic halibut (Hippoglossus hippoglossus) fed diets differing in the ratio between the macronutrients. Aquaculture, 166: 49-56. https:// doi.org/10.1016/S0044-8486(98)00273-7

Hemre, G.I., Mommsen, T. and Krogdahl, A., 2002. Carbohydrates in fish nutrition: Effects on growth, glucose metabolism and hepatic enzymes. Aquacult. Nutri., 8: 175-194. https://doi.org/10.1046/j.13652095.2002.00200.x

Hillestad, J. and Austreng, Å., 1998. Long-term effects of dietary fat level and feeding rate on growth, feed utilization and carcass quality of Atlantic salmon. Aquacult. Nutr., 4: 89-97. https://doi.org/10.1046/ j.1365-2095.1998.00051.x

Hilton, J.W. and Atkinson, J.L., 1982. Response of rainbow trout (Salmo gairdneri) to increased levels of available carbohydrate in practical trout diets. Br. J. Nutr., 47: 597-607. https://doi.org/10.1079/ BJN19820071

Hu, Y.H., Liu, Y.J., Tian, L.X., Yang, H.J., Liang, G.Y. and Gao, W., 2007. Optimal dietary carbohydrate to lipid ratio for juvenile yellowfin seabream (Sparus latus). Aquacult. Nutr., 13: 291-297. https://doi. org/10.1111/j.1365-2095.2007.00476.x

Jiang, Y., Wang, J., Han, T., Li, X. and Hu, S., 2015. Effect of dietary lipid level on growth performance, feed utilization and body composition by juvenile red spotted grouper (Epinephelus akaara). Aquacult. Int., 23: 99-110. https://doi.org/10.1007/ s10499-014-9801-7

Kim, J. and Khan, W., 2013. Goblet cells and mucins: Role in innate defense in enteric infections. Pathogens, 2: 55-70. https://doi.org/10.3390/ pathogens 2010055

Kohla, U., Saint-Paul, U., Friebe, J., Wernicke, D., Bfa, V.H., Bravm, E. and Gropp, J., 1992. Growth, digestive enzyme activities and hepatic glycogen levels in juvenile Colossoma macropomum Cuvier from South America during feeding, starvation and refeeding. Aquacult. Res., 23: 189-208. https://doi. org/10.1111/j.1365-2109.1992.tb00610.x

Krogdahl, A., Hemre, G.I. and Mommsen, T.P., 2005. Carbohydrates in fish nutrition: Digestion and absorption in postlarval stages. Aquacult. Nutr., 11: 103-122. https://doi.org/10.1111/j.13652095.2004.00327.x

Liu, Y., Hu, J., Zhou, S., Yang, R., Qin, J., Ma, Z. and Yang, Q., 2018. Effect of acute ammonia stress on antioxidant enzymes and digestive enzymes in Barramundi Lates calcarifer larvae. Isr. J. Aquacult. 
Bamid., 70: 1508-1519.

Lundstedt, L.M., Fernando Bibiano Melo, J. and Moraes, G., 2004. Digestive enzymes and metabolic profile of Pseudoplatystoma corruscans (Teleostei: Siluriformes) in response to diet composition. Comp. Biochem. Physiol. B: Biochem. mol. Biol., 137: 331-339. https://doi.org/10.1016/j. cbpc.2003.12.003

Ma, X., Hu, Y., Wang, X., Ai, Q., He, Z., Feng, F. and Lu, X., 2014. Effects of practical dietary protein to lipid levels on growth, digestive enzyme activities and body composition of juvenile rice field eel (Monopterus albus). Aquacult. Int. J. Eur. Aquacult. Soc., 22: 749-760. https://doi.org/10.1007/s10499013-9703-0

Ma, Z., Yu, G., Meng, X. and Chen, M., 2019. Barramundi breeding biology and processing: edn. China Agriculture Press, Beijing.

Ma, Z., Hassan, M.M., Allais, L., He, T., Leterme, S., Ellis, A.V., McGraw, B. and Qin, J.G., 2018. Replacement of fishmeal with commercial soybean meal and EnzoMeal in juvenile barramundi Lates calcarifer. Aquacult. Res., 49: 3258-3269. https:// doi.org/10.1111/are.13790

Ma, Z., Hassan, M.M., Allais, L., He, T., Leterme, S., Ellis, A., McGraw, B. and Qin, J.G., 2019. Comparison of partial replacement of fishmeal with soybean meal and EnzoMeal on growth performance of Asian seabass Lates calcarifer. Comp. Biochem. Physiol. C: Toxicol. Pharmacol., 216: 29-37. https://doi.org/10.1016/j.cbpc.2018.10.006

Magnoni, L.J., Eding, E., Leguen, I., Prunet, P., Geurden, I., Ozório, R.O.A. and Schrama, J.W., 2018. Hypoxia, but not an electrolyte-imbalanced diet, reduces feed intake, growth and oxygen consumption in rainbow trout (Oncorhynchus mykiss). Sci. Rep. U.K., 8: 4965. https://doi. org/10.1038/s41598-018-23352-Z

Meng, Y., Qian, K., Ma, R., Liu, X., Han, B., Wu, J., Zhang, L., Zhan, T., Hu, X., Tian, H. and Li, C., 2019. Effects of dietary lipid levels on subadult triploid rainbow trout (Oncorhynchus mykiss): Growth performance, digestive ability, health status and expression of growth-related genes. Aquaculture, 513: 734394. https://doi. org/10.1016/j.aquaculture.2019.734394

Merrifield, D.L., Harper, G.M., Mustafa, S., Carnevali, O., Picchietti, S. and Davies, S.J., 2011. Effect of dietary alginic acid on juvenile tilapia (Oreochromis niloticus) intestinal microbial balance, intestinal histology and growth performance. Cell Tissue Res., 344: 135-146. https://doi.org/10.1007/ s00441-010-1125-y

Mohanta, K.N., MonantyY, S.N., Jena, J.K. and Sahu, N.P., 2008. Optimal dietary lipid level of silver barb, Puntius gonionotus fingerlings in relation to growth, nutrient retention and digestibility, muscle nucleic acid content and digestive enzyme activity. Aquacult. Nutr., 14: 350-359. https://doi. org/10.1111/j.1365-2095.2007.00542.x

Muzinic, L.A., Thompson, K.R., Metts, L.S., Dasgupta, S. and Webster, C.D., 2006. Use of turkey meal as partial and total replacement of fish meal in practical diets for sunshine bass (Morone chrysops $\times$ Morone saxatilis) grown in tanks. Aquacult. Nutr., 12: 71-81. https://doi.org/10.1111/j.1365-2095.2006.00387.x

Nagase, G., 1964. Contribution to the physiology of digestion in Tilapia mossambica Peters: Digestive enzymes and the effects of diets on their activity. Z. vergleich. Physiol., 49: 270-284. https://doi. org/10.1007/BF00298199

Nankervis, L., Matthews, S.J. and Appleford, P., 2000. Effect of dietary non-protein energy source on growth, nutrient retention and circulating insulinlike growth factor I and triiodothyronine levels in juvenile barramundi, Lates calcarifer. Aquaculture, 191: 323-335. https://doi.org/10.1016/S00448486(00)00436-1

Ngoh, S.Y., Tan, D., Shen, X., Kathiresan, P., Jiang, J., Liew, W.C., Thevasagayam, N.M., Kwan, H.Y., Saju, J.M., Prakki, S.R.S., Goh, C.H., Wong, H.C., Chan, T.T., Mézes, M. and Orbán, L., 2015. Nutrigenomic and nutritional analyses reveal the effects of pelleted feeds on asian Seabass (Lates calcarifer). PLoS One, 10: e145456. https://doi. org/10.1371/journal.pone.0145456

NRC, 2011. Nutrient requirements of fish and shrimp. edn. The national academies press, Washington DC.

Panserat, S., Medale, F., Blin, C., Breque, J., Vachot, C., Plagnes-Juan, E., Gomes, E., Krishnamoorthy, R. and Kaushik, S., 2000. Hepatic glucokinase is induced by dietary carbohydrates in rainbow trout, gilthead seabream, and common carp. Am. J. Physiol. Regul. Integr. Comp. Physiol., 278: R1164-R1170. https://doi.org/10.1152/ ajpregu.2000.278.5.R1164

Peragón, J., Barroso, J.B., García-Salguero, L., de la Higuera, M., Lupiáñez, J.A., 1999. Carbohydrates affect protein-turnover rates, growth, and nucleic acid content in the white muscle of rainbow trout (Oncorhynchus mykiss). Aquaculture, 179: 425-437. https://doi.org/10.1016/S00448486(99)00176-3 
Reimer, G., 1982. The influence of diet on the digestive enzymes of the Amazon fish Matrincha, Brycon cf. melanopterus. J. Fish Biol., 21: 637-642. https:// doi.org/10.1111/j.1095-8649.1982.tb02867.x

Ren, M., Ai, Q., Mai, K., Ma, H. and Wang, X., 2011. Effect of dietary carbohydrate level on growth performance, body composition, apparent digestibility coefficient and digestive enzyme activities of juvenile cobia, Rachycentron canadum L. Aquacult. Res., 42: 1467-1475. https://doi. org/10.1111/j.1365-2109.2010.02739.x

Ren, W., Li, J., Tan, P., Cai, Z., Mai, K., Xu, W., Zhang, Y., Nian, R., Macq, B. and Ai, Q., 2018. Lipid deposition patterns among different sizes of three commercial fish species. Aquacult. Res., 49: 10461052. https://doi.org/10.1111/are.13553

Schrama, J.W., Saravanan, S., Geurden, I., Heinsbroek, L.T.N., Kaushik, S.J. and Verreth, J.A.J., 2011. Dietary nutrient composition affects digestible energy utilisation for growth: A study on Nile tilapia (Oreochromis niloticus) and a literature comparison across fish species. Br. J. Nutr., 108: 277-289. https://doi.org/10.1017/S0007114511005654

Sørensen, M., 2012. A review of the effects of ingredient composition and processing conditions on the physical qualities of extruded high-energy fish feed as measured by prevailing methods. Aquacult. Nutr., 18: 233-248. https://doi.org/10.1111/j.13652095.2011.00924.x

Stone, D.A.J., 2003. Dietary carbohydrate utilization by fish. Rev. Fish. Sci., 11: 337-369. https://doi. org/10.1080/10641260390260884

Sun, Z., Tan, X., Ye, H., Zou, C., Ye, C. and Wang, A., 2018. Effects of dietary Panax notoginseng extract on growth performance, fish composition, immune responses, intestinal histology and immune related genes expression of hybrid grouper (Epinephelus lanceolatus $\hat{\sigma} \times$ Epinephelus fuscoguttatus ㅇ) fed high lipid diets. Fish Shellf. Immun., 73: 234-244. https://doi.org/10.1016/j.fsi.2017.11.007

Torfi Mozanzadeh, M., Yavari, V., Marammazi, J.G., Agh, N. and Gisbert, E., 2017. Optimal dietary carbohydrate-to-lipid ratios for silvery-black porgy (Sparidentex hasta) juveniles. Aquacult. Nutr., 23: 470-483. https://doi.org/10.1111/anu.12415
Trenzado, C.E., Carmona, R., Merino, R., GarcíaGallego, M., Furné, M., Domezain, A. and Sanz, A., 2018. Effect of dietary lipid content and stocking density on digestive enzymes profile and intestinal histology of rainbow trout (Oncorhynchus mykiss). Aquaculture, 497: 10-16. https://doi.org/10.1016/j. aquaculture.2018.07.031

Vasanthan, T., Yeung, J. and Hoover, R., 2001. Dextrinization of starch in barley flours with thermostable alpha-amylase by extrusion cooking. Starch - Stärke, 53: 616-622. https://doi. org/10.1002/1521-379X(200112)53:12<616::AIDSTAR616>3.0.CO;2-M

Wang, J., Liu, Y., Tian, L., Mai, K., Du, Z., Wang, Y. and Yang, H., 2005. Effect of dietary lipid level on growth performance, lipid deposition, hepatic lipogenesis in juvenile cobia (Rachycentron canadum). Aquaculture, 249: 439-447. https://doi. org/10.1016/j.aquaculture.2005.04.038

Wang, L., Hu, S., Lou, B., Chen, D., Zhan, W., Chen, R., Liu, F. and Xu, D., 2018. Effect of different dietary protein and lipid levels on the growth, body composition, and intestinal digestive enzyme activities of juvenile yellow drum Nibea albiflora (Richardson). J. Ocean U. China, 17: 1261-1267. https://doi.org/10.1007/s11802-018-3660-1

Zhao, P., Li, F., Chen, X., Chen, Y., Lin, S., Zhang, L. and Li, Y., 2016. Dietary lipid concentrations influence growth, liver oxidative stress, and serum metabolites of juvenile hybrid snakehead (Channa argus $\times$ Channa maculata). Aquacult. Int., 24: 1353-1364. https://doi.org/10.1007/s10499-0169993-0

Zheng, K., Dou, B., Xu, H. and Liang, M., 2015. Effect of dietary cornstarch level on the growth performance of japanese seabass (Lateolabrax japonicus) in grow-out phase. Israeli J. Aquacult., 67: 1210-1218.

Zhou, P., Wang, M., Xie, F., Deng, D. and Zhou, Q., 2016. Effects of dietary carbohydrate to lipid ratios on growth performance, digestive enzyme and hepatic carbohydrate metabolic enzyme activities of large yellow croaker (Larmichthys crocea). Aquaculture, 452: 45-51. https://doi.org/10.1016/j. aquaculture.2015.10.010 